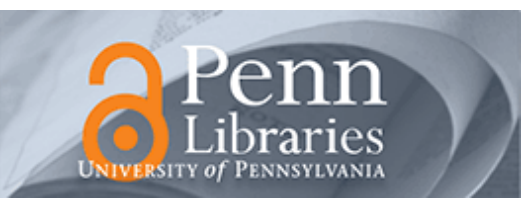

University of Pennsylvania

ScholarlyCommons

$5-2009$

\title{
Teacher Identity in the Context of Literacy Teaching: Three Explorations of Classroom Positioning and Interaction in Secondary Schools
}

\author{
Leigh A. Hall \\ University of North Carolina \\ Amy Suzanne Johnson \\ University of South Carolina \\ Mary M. Juzwik \\ Michigan State University \\ Stanton Wortham \\ University of Pennsylvania, stanton.wortham@bc.edu \\ Melissa Mosley \\ University of Texas at Austin \\ Follow this and additional works at: https://repository.upenn.edu/gse_pubs \\ Part of the Education Commons
}

\section{Recommended Citation}

Hall, L. A., Johnson, A. S., Juzwik, M. M., Wortham, S., \& Mosley, M. (2009). Teacher Identity in the Context of Literacy Teaching: Three Explorations of Classroom Positioning and Interaction in Secondary Schools. Retrieved from https://repository.upenn.edu/gse_pubs/213

Suggested Citation:

Hall, L. et al. (2009) "Teacher Identity in the Context of Literacy Teaching: Three Explorations of Classroom

Positioning and Interaction in Secondary Schools." Teaching and Teacher Education. Vol. 26(2). p. 234-243.

The final version of this article is available at http://dx.doi.org/10.1016/j.tate.2009.04.009

This paper is posted at ScholarlyCommons. https://repository.upenn.edu/gse_pubs/213

For more information, please contact repository@pobox.upenn.edu. 


\title{
Teacher Identity in the Context of Literacy Teaching: Three Explorations of Classroom Positioning and Interaction in Secondary Schools
}

\begin{abstract}
This article presents the results of three separate studies of literacy teaching and learning in the U.S. that explore the social functions of language, specifically focused on the identity development of literacy learners and teachers. Each study offers a detailed account of how literate identities are constructed and enacted and the positive and negative consequences that occur for teachers and students when they are enacted. Taken together, these three studies demonstrate how teachers' and students' understandings of identity can promote or inhibit literacy teaching and learning.
\end{abstract}

\section{Keywords}

Identity, literacy, language

Disciplines

Education

\section{Comments}

\section{Suggested Citation:}

Hall, L. et al. (2009) "Teacher Identity in the Context of Literacy Teaching: Three Explorations of Classroom Positioning and Interaction in Secondary Schools." Teaching and Teacher Education. Vol. 26(2). p. 234-243.

The final version of this article is available at http://dx.doi.org/10.1016/j.tate.2009.04.009 
Teacher Identity in the Context of Literacy Teaching:

Three Explorations of Classroom Positioning and Interaction in Secondary Schools

\begin{abstract}
This article presents the results of three separate studies of literacy teaching and learning in the U.S. that explore the social functions of language, specifically focused on the identity development of literacy learners and teachers. Each study offers a detailed account of how literate identities are constructed and enacted and the positive and negative consequences that occur for teachers and students when they are enacted. Taken together, these three studies demonstrate how teachers' and students' understandings of identity can promote or inhibit literacy teaching and learning.
\end{abstract}

Keywords: Identity, literacy, language 


\section{Literacy and the Social Functions of Language:}

Three Explorations into Identity Development in Adolescent and Adult Literacy

\section{Introduction}

In schools and communities across the U.S, language functions as a social tool for helping individuals understand themselves, each other, and their world and plays an important role in how individuals develop their identities, accomplish social action, and are positioned in and outside of school (Orellana, 2007). Through written and spoken language, individuals can send and receive messages, develop or end relationships, provide feedback, and attempt to influence each other (Johnston, 2004). As many studies in the U.S. have documented, language use serves as a way for people to learn what is or is not valued within a community, establish social identities for themselves and others, develop understandings about texts, and gain access to tools that can facilitate their reading comprehension or production of written texts (Agha, 2007; Austin, 1956; Eckert, 2000; Goffman, 1981; Gumperz, 1982; Hymes, 1964; Labov, 1972; Mehan, 1996; Searle, 1969).

Researchers have documented within the U.S. (Street, 2005), Australia (Luke, 1995; 2004), and the United Kingdom (Comber \& Kamler, 2004) that how individuals engage with or make decisions about the ways to read and write in their schools and communities still tend to be described in terms of skills or what one can or cannot do with little understanding or attention to the social and cultural practices which influence both the literate acts and development of individuals. Teachers and schools often ascribe identities to students, such as good reader or poor writer, based on their understanding of what each identity entails (McDermott, Goldman, \& Varenne, 2006; Wortham, 2006). Often these identities are narrow and students are expected to 
take up the literacy practices valued within their classrooms or risk being marginalized (First Author, 2006).

Research on American students and their families suggests that as they interact with schools, and learn what constitute more or lesser valued identities, they may begin to adopt the language teachers use to describe what it means to be literate and use it as a way to understand themselves as readers and writers (Rogers, 2002). When teachers do not promote a view of identity development as one that is flexible and open for discussion, students may believe the models promoted by their teachers are being forced upon them (Skeggs, 2008). Students and families who relinquish the power to control the development of their literate identities to schools can compromise who they become as individuals (Moje \& Lewis, 2007). Indeed, literacy learning leads to changes in identity, but not always in empowering or transformative ways.

How students engage with or make decisions about the ways they read and write within social spaces thus has social, material, and psychological consequences that can influence an individual's literacy practices (First Author, in press; Lewis, 2001). As Packer and Goicoechea (2000) describe, a schooled cognitive accomplishment like learning to read and write changes not just what the learner knows but also who the learner is. It is an ontological as well as an epistemological transformation. The social acts that people accomplish with language play a central role in making students and teachers the types of people they are, and literacy practices inside and outside school represent one type of language use that does this work.

The social functions of language are then central to literacy research, because becoming a reader or writer means changing one's social identity, particularly for those whose literacy practices are not valued in schools (Bartlett, 2005; Bernhard et. al, 2006). Research on the social functions of language has illuminated the emergence and consequences of identities and how 
people develop literate identities around the world including the U.S. (First Author, 2009;

Kramer-Dahl, 2000) and South America (Bartlett, 2007). As students' approaches to the literacy practices demanded in schools develop, a look at the social functions of language can trace their emerging identities as different kinds of literate people. Tracing the social functions of language, then, can help us understand how these literate identities emerge dialogically in relation to individuals' contexts. That is to say, examining the social functions of language entails scrutinizing how identities emerge through engagement with talk, texts, and other forms of semiotic interaction (e.g., gesture) within specific social settings.

This article offers three explorations of the social functions of language, specifically focused on how identities are developed and enacted by literacy learners and teachers within the U.S. The studies show how identity processes work at different levels of time and how individuals' experiences in school, at both micro and macro levels, shape their literate identities. Taken together, the three studies demonstrate the immediate and long-lasting effects literacy instruction can have on literate identities and suggest the consequences of such effects.

The first two studies are situated in American middle schools, and the third focuses on the identity development of a beginning American teacher. American middle schools are attended by students in their sixth, seventh, and eighth year of schooling. Students are approximately 12-14 years old and are often referenced in relation to the grade they are in (a sixth-grader or an eighth-grader for example).

First, [third author] explores storytelling as a discursive resource through which Ms. Wagner (all names are pseudonyms) and her sixth-grade students' identities emerge and become interwoven with curricular content within a two-hour period. Next, [first author] examines how three teachers' language use informs the construction of reading identities for three middle 
school students over the period of one academic year. Finally, [second author] illustrates how the life experiences of a pre-service teacher, Rachel Rosenburg, influenced her current literate identity and her beliefs about her future role as a literacy teacher.

\section{Theoretical Framework}

Language and literacy are culturally situated and their use depends on the social goals for the community within which they are located. Scribner (1984) provided three metaphors that can be used to examine the social functions of language for people around the world who are situated within varying socio-cultural contexts. First, she noted that individuals develop and engage in literacy practices in order to adapt or survive within their environment. Second, she argued that language and literacy can be used to help empower communities or groups, or access to literacy can be diminished in order to prevent particular groups from acquiring power to create change. Finally, she posited that literacy is also a form of salvation or "state of grace," because literacy enables individuals to participate in the spiritual and religious practices that hold status in their communities.

Scribner's (1984) metaphors suggest that language and literacy are used by people to position themselves and each other to accomplish social goals. Positioning happens primarily through conversation (Davies \& Harré, 1999). Individuals use speech as a way to communicate and understand what is means to be a particular type of person within a specific context. As people learn the characteristics associated with the identities available to them, they can adopt the language and speech patterns connected to them in order to position themselves as a certain type of person (Bakhtin, 1935/1981). Within a given context, there exists a collective agreement regarding how people can be identified and the characteristics associated with the various identities (Wortham, 2006). 
Some identities have more value than others. People who possess valued identities have identity capital (Corté \& Levine, 2002). As Wortham's (2006) account of an American high school English class demonstrated, individuals who show that they have and know how to use identity capital in a socially accepted way position themselves to be identified positively and receive privileges. Therefore, people may find that their ability to succeed within a given context may be tied to the socially accepted identity and their willingness to acquire it or enact it. Individuals can then use language to construct identities and position themselves in ways they believe will meet their social and academic goals (Duzak, 2002).

In addition to positioning oneself, people can also interactively position each other through conversation (Davies \& Harré, 1999; Wortham, 2001). Language can be used to communicate what it means to posses a certain identity and who does and does not have it. Interactive positioning can communicate status and power as individuals suggest what valued identities look like, who has them, and who does not. However, such positioning is not always intentional, and individuals may not be aware that they are engaging in it.

\section{Performing Teacher Identity in a Middle School English Classroom}

The study of narrative discourse has been one means for understanding teachers' identities. In a recent project, I ([third author]) have been to understand teachers' identities by looking closely at how teachers use oral narratives as identity building resources. I specifically ask: How does one teacher socially position herself in the unfolding discourse of a middle school English classroom? By framing my interest in teacher identity in terms of positioning, this account seeks to understand English teacher identity as fluid, dynamic, emergent in situ and also as consequentially interconnected with the content of the curricular conversations in the domains of literacy (Applebee, 1996; Wortham, 2006). 
I offer a micro-linguistic dialogic analysis of classroom narratives as oral performance (Bakhtin, 1981, 1984, 1986; Georgakopoulou, 1998; Wortham, 2001). Looking closely at multiple timescales of classroom interactions can illuminate how teacher identity (or the social identification of the teacher) works as a process of interactional positioning emergent over multiple timescales within a two-hour period (Lemke, 2000; Wortham, 2006). Lemke (2000) explains the concept of timescales using notations of $\mathrm{N}$ (focal timescale), $\mathrm{N}+1$ (a slightly longer timescale process than $\mathrm{N}$ ), and $\mathrm{N}-1$ (the slightly shorter timescale process than $\mathrm{N}$ ): "what is possible on the focal scale ... depends on the kinds of processes and participants at the level immediately below, level $\mathrm{N}-1 \ldots$ interactions... are also constrained by being ... part of longer timescale processes at Level $\mathrm{N}+1$. The longer-scale processes determine what is probable at the focal level" (Lemke, pg. 277).

Timescales are useful for distinguishing between the narrated event, the past events reconstructed and recontextualized in narrative form, and the storytelling event, the interactional situation in the "here and now" that includes multiple interlocutors, context, turn-taking, and so on. It is in the "here and now," as students and teacher interact with one another and with literacy curriculum, that I trace interactional positioning of teacher, and her performance of a "literacy teaching self," in relation to students. Through this analytic lens, oral teacher narratives can be reframed as significant means of positioning selves (and others) in classrooms.

We shall look closely at data generated in a case study about writing instruction and narrative language in an urban middle school classroom. In literacy classrooms, oral narratives and written language (e.g. literature, students' written narratives), can become resources for positioning selves and being positioned by others in a range of ways. The teacher, Ms. Wagner, was a white woman, who at the time of the study was an 11-year veteran teacher, in a classroom 
of mostly African-American 6th graders. A narrative, titled "My worst mistake," serves as the focal event, or "focal scale" (Lemke, 2000) of this analysis. This narrative event lasted 2 min., 23 sec. $(\mathrm{N}=2: 23)$. The narrative performance began with the teacher reading a written narrative, but then broke through into a full performance around line 34:

Ms. Wagner ((sitting behind desk))

\section{Okay}

2. Here's mine

3. And I only got through part of it.

4. Shh

5. I put

((reading))

6. Making a mistake

7. Is like sta:bbing your own soul.

8. It can be detrimental to your growth?

9. And damaging to your self-este:em.

10. I de $\uparrow$ test making mistakes

11. Whether major

12. Or minor

13. In form.

14. It bothers me

15. Because I could fe:el

16. As if 
17. I'm inadequate

18. Or a poor decision maker.

19. My worst mistake

20. Ever

21. Was the day I let

22. my older brother

23. Convince me

24. To smoke

25. Cigarettes with him

26. S: ((laugh))

27. And his friends.

28. Of course?

29. I was o:nly about

30. Eight years o:ld.

31. Ss: OOHhhh[hhhhh

32. T: [So I can't be he:ld (1) 
33. Fully responsible. ((stands up, walks in front of desk, no longer reading))

34. [And then what my dad did

35. S $[(($ laughs $))$

36. $\mathrm{T}$ : is

\section{7. >kind of like how I teach you kids sometimes<}

38. Becau:se I smoked

39. And got cau:ght?

40. Student: made you smoke some=

41. $\mathrm{T}:=\mathrm{We}$ had to $\uparrow \underline{\mathrm{smo}}: \mathrm{ke}=$

42. Student =got a who:le pack=

43. $\mathrm{T}:=$ And $\uparrow \underline{\underline{s m o}: \mathrm{ke}}=$

44. Student: =not just (one?)

45. Ss: $\quad[(($ talking, laughing, unintelligible $))$

46. T: [Unti:1 
47. Ss: $\quad[(($ talking, laughing, unintelligible $))$

48. T: He uh musta ha:d

49. I don't know

50. $\underline{\uparrow \mathrm{Pa}: \mathrm{cks}}$ and $\uparrow$ pa:cks

51. Ss: (inaudible)

52. T: And we had to $\uparrow$ smo:ke them

53. With him,

54. S: This a real [story?

55.

56. T: [until they

57. Ye::s

58. S: Did you get a he:adache?

59. T: Until they were $\uparrow$ go:ne,

60. And I was $\uparrow \underline{\text { si:ck }}$

61. 'I mean if you're not a smoker,

62. I didn't even know how to smoke,

63. I was $\uparrow \underline{\text { cry: }}$ :in 
64. And he took $\uparrow$ pi:ctures

65. Ss: ((laugh))

66. T: [ (inaudible) (smo:ke)

67. And he said,

68. These are pictures of my $\uparrow \underline{\mathrm{ki}: \mathrm{ds}}$

69. I'm so proud of them

70. A $\uparrow$ smo:king?

71. And we had to like po:se?

72. With $\uparrow$ cigarettes in our mouths

73. Ss: ((laughing))

74. Everything you can think of

75. And my dad did

76. And

77. I just remember walking

78. after we got caught

79. Walking with my brother

80. So

81. my brother's only a year older 
82. So he's like

83. nine

84. and uh

85. So at the time I remember

86. When we got $\uparrow \underline{\text { caught }}$

87. And we had to walk towards our house

88. From the neighbor's house

89. and

90. my brother was goin

91. ${ }^{\circ}$ we'll just tell mom and dad

92. that this is a $\uparrow \underline{\text { ha:bit }}$

93. of ours ${ }^{\circ}$

94. Ss: ((laughing))

95. T: that we don't know how to $\uparrow$ quit it

96. and

97. Ss: ((laughing))

98. T: He was saying (think?) you know

99. he’s only $\uparrow$ nine 
100. so we had to do $\uparrow$ tha:t.

101. and he $\uparrow \underline{\text { di }:: \mathrm{d}}$

102. have them developed.

103. and he $\uparrow \underline{\text { di:::d }}$

104. show people,

105. the pictures

106. of us.

107. And of course we were crying

108. It wasn’t like $\uparrow$ funny (scene/seeing)

109. And he $\uparrow$ still

110. Has those pictures.

111. And so [basically

112. Ss: ((animated talking))

113. ((rhythmically)) bring 'em,

114. [bring 'em,

115. bring 'em

116. T: [No:hohoho ((shaking head dramatically))

117. No:::::

118. And he 
119. Ss ((talking))

120. He $\uparrow \underline{b a: s i c a l l y ~}$

121. Did what to me?

122. Ss: ((talking))

123. T: Humiliated me $\downarrow$ ::

124. So؟much

125. Do you think I smoke?

126. Ss: ((in chorus)) NO::

127. T: Never even had the desi:re to smoke.

According to Lemke (2000), multiple timescales (at least three, including the focal time scale) are needed to capture the broader social and interactional ecologies in which identities emerge and unfold. I will focus on four distinct timescales: (a) the narrative event $(\mathrm{N}=2: 23$ minutes), (b) the multiple interactional moments comprising the narrative event $(\mathrm{N}-1=0-2: 23$ minutes), (c) the literacy event $(\mathrm{N}+1=30$ minutes $)$; and (d) the class session $(\mathrm{N}+2=2$ hours $)$. At the level of micro-interaction within the narrative event, teacher and students make numerous positioning moves. The students' exclamation “OOHhhhhhh” (line 31) seems to invite Ms. Wagner into a performance of the full story- something she might not have done without this encouragement. Students are positioning her as an entertainer and themselves as eager audience members. Students also join into co-telling of the narrative, for example rhythmically 
anticipating and elaborating the teacher story in line 40, "made you smoke some=", line 42, "=got a who:le pack=", and line 44, "=not just one." Analysis of positioning at this level, then, attends to the micro-interactional dynamics through which the narrative emerges and describes how teacher identity emerges through the narrative. What happens interactionally at this level constrains what may happen in the narrative event as a whole.

Looking at the narrative event level entails observing the narrative as a "speech genre" with certain textual (and quite possibly, intertextual) features. In terms of narrative structure (e.g., orientation, abstract, evaluation, complication, resolution, coda [Labov, 1972]), this narrative can be seen as a fully formed story with a clear beginning, middle, and end, that draws on a considerable range of resources for structuring and sequencing past events. Textual features such as parallelism can also be observed: for example the thematic parallelism suggested between the actions of the Teacher's father and the actions of the Teacher: both use humiliation techniques so that young people will learn (line 37, lines 123-127). Other textual properties to be examined include coherence ties (Halliday \& Hasan, 1977), constructed dialogues, other forms of parallelism, and rhythm (e.g., the emphasis on the final word of many lines, which seem to represent a particular regional Midwestern accent). Although I do not have space here to elaborate a full analysis of narrative event, interested readers should see Third Author (2008).

In this instructional episode, which lasts approximately 30 minutes, students were sharing their narrative writing about "my worst mistake." The teacher's narrative became a turn in this literacy event, responding to prior turns and anticipating subsequent turns. In this sense, we can see at this level how both the oral teacher narrative and the written (and then spoken) student narratives became links in what Bakhtin (1981) called a "chain of speech communication." For example, a student, Tiger, recounted his smoking narrative three turns prior to the teacher 
narrative. Tiger's friend suggested they smoke Newports, an American cigarette brand. This narrative then became a resource for Ms. Wagner's narrative:

My worst mistake is last summer, my cousin and some friends and I were (inaudible) at the park. My friend pulled out a pack of Newports. I said "What are you doing?" He said, "Let's smoke guys." Then he lighted it. Then he, then he started and turned towards me. I felt nervous and scared because the security come up to the park and check and see if anything is wrong every thirty minutes. If he caught us smoking, he would take us to, he would take us home and tell our parents what we were doing. And I was the oldest and they would have blamed me. So I took, uh, so I took them and ran back home. I told my parents and then they called my friends' mothers and fathers. Their parents were very upset. Then they got whupped (spanked). Then my parents whupped my cousins. Afterwards, I felt like I was the one who was smoking. Smoking is like killing yourself. Then my parents told me, then my parents told me that that was the right thing to do. They told me don't smoke because it messes up your lungs.

Tiger's narrative provides topic (e.g., illicit smoking as "worst mistake"), theme (the moral stance that "smoking is bad"; the parental mandate not to smoke), and even structure (a clear beginning, middle, end) that Ms. Wagner subsequently appropriates in her narrative. And, in turn, the teacher narrative became a resource for Candy's subsequent smoking narrative, in the next narrative turn after the focal teacher narrative: "My brother he had uh, his friend, they had uh, took a pack of his daddy's cigarettes and they went into my grandma's basement and smoked it. They tried to get me down there and I said, 'No, y'all gonna get it!'” Although this story is not so fully formed, we can observe here again the recontextualization of the illicit smoking topic, the moral stance that "smoking is bad," the construction of an identity through reported 
speech, and the relationship with an authoritative figure who would punish them for smoking (a grandparent, rather than parent, in this case).

Events at the level of the two-hour class session further aid interpretation of the focal narrative event as part of the emergent positioning of teacher identity in the classroom. The class was in the midst of reading the young adult novel Hatchet, by Gary Paulson and Ms. Wagner led the following question/answer session early on in the 2-hour period ( "My worst mistake" came near the end of the two-hour session):

Ms. W.: Five. What does Gary Paulsen mean by "owns them", when on page 121 he says, "he knew Brian, knew him and owned him." First of all, what's he talking about?

Ss: (All answering at once, most responses inaudible) Survival.

Ms. W.: The wolf.

T: Look at 121, what do you think Della?

Della: Uh, Uh if you make that the wolf that Brian was scared of him and he wouldn't do anything to em.

Ms. W.: In the woods, who do you think is higher up, a wolf or Brian?

Ss ((in unison)): The wolf.

Ms. W.: The wolf. So Brian is owned by the wolf because what does the wolf own?

Ss: The territory.

Ms. W.: The territory. And Brian was in his territory. And so, it's like you coming in this classroom. You're walking into MY territory. Now all of us work in it, and we want to be a team, but I am going to tell you what to do. So, I'm like the wolf. And you are like who?

Students ((in unison)): Brian. 
This discussion of the novelistic content seems to anticipate Ms. Wagner's positioning later on in "My Worst Mistake" as someone who, like her father, humiliates students to teach them important lessons. Here Ms. Wagner likens herself to the wolf in the book Hatchet and her classroom to a wolf's territory that students are entering at their own peril. This teacher/student positioning is related to that performed in her "My Worst Mistake" narrative by harshness and an

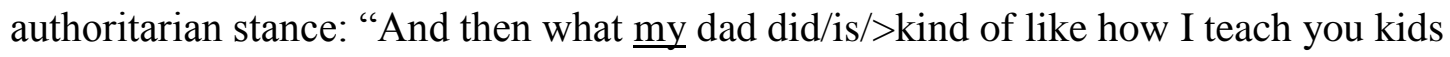

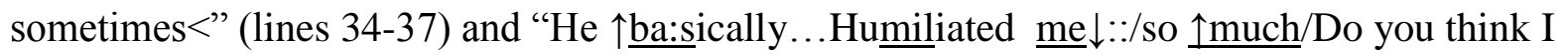
smoke?.../Never even had the desi:re to smoke" (lines 120-127). This positioning moreover seems consistent with Ms. Wagner's likening herself to a wolf earlier on in the class period. This wolf-like positioning, although it may horrify some readers, was not strange or unusual: while the interactional analysis of Ms. Wagner's own narrative might have suggested a highly dialogic classroom, being "student-centred" did not seem to be part of Ms. Wagner's longer-term identification (See Second author and Ives, in preparation). She was not particularly interested in positioning herself in this way, and her students rarely - if ever - positioned her thus. Although beyond the scope of these interactional data, Ms. Wagner was perceived by others (e.g., African-American leaders in the district) as an authoritarian- like her father in her "My Worst Mistake" narrative, not afraid to humiliate her students - and she earned respect for this stance. In likening herself to a wolf and her classroom to a wolf's territory in literary conversation, moreover, Ms. Wagner mobilized the metaphorical resource of literary narrative, just as she mobilized the metaphorical resource of oral narrative later on, to position herself as literacy teacher.

By looking across timescales, with the focal narrative event as our locus of attention, several observations about how Ms. Wagner positioned herself and was positioned by others can 
be made. First, she actively presented herself as a successful storyteller who responds to and entertains her audience through moment-by-moment interactions. She also actively positioned herself as a one-time kid, making a mistake and getting caught and learning from the experience. Further, she actively presented herself in a teacher/student role: someone who sometimes "humiliates" "you kids" to teach, like her father did with her. Finally, she drew upon the curricular resources of literacy - including oral narrative talk, written narrative, and metaphor to do this ongoing identity work. I believe the identity work discussed in this analysis would have differed significantly in a different curricular conversation (e.g., math). There are of course slower timescales to be considered: Her identity work had been in process for over ten years of her teaching life: this analysis represents merely a synchronic snapshot within the broader context of an ongoing teacher identification process across her career. Rather than remaining static, however, her identity was dynamic work and contingent upon positioning moves by different persons, at different timescales of classroom life.

Certainly, this is little more than a sketch of theoretical possibility and further evidence would be needed to give a full account of emergent teacher identity. These data could include other narrative performances, interviews (including life stories), curricular documents, and writing prompts. What we do have here, though, is an effort to understand teachers as active and productive creators of their own identities using the social and interactional resources available to them through literacy classroom interaction.

\section{Constructing Students' Reading Identities in Middle School Classrooms}

As the first study showed, teachers can use language to position themselves in classrooms and develop their identities with their students. However, teachers can also use language to position students, suggest what identities are available to them, and influence their current and 
developing identities. In this second study, I [first author] present the findings from a year-long, cross-case analysis examining how three pairs of middle school teachers and struggling readers understood the different reading identities that were available to them and how they worked with texts and each other based on the identities they adopted, placed on each other, wanted to obtain, or wanted to avoid.

Participants included Mrs. O’Reilly and Sarah, sixth-grade social studies, Mrs. Harding and Nicole, seventh-grade mathematics, and Mrs. Baker and Alisa, eighth-grade science. Each teacher was certified to teach the grade level and content area she taught. None of the teachers had an English Education background or had recently participated in professional development related to teaching reading. However, each stated in our initial conversations that many of their students had difficulties comprehending texts and they wanted to help them improve as readers in order to increase their learning of content. They explained that they relied on the internet and speaking to their colleagues to help them address their students' reading needs.

The participating students were considered to be struggling readers. Struggling readers were defined by the researcher as students who read one or more years below their current grade level and did not have a learning disability (Ruddell \& Shearer, 2002). Informal reading assessments administered by the students' language arts teachers at the end of the previous academic year and by First Author at the beginning of the study showed that Sarah read on a fourth-grade level while Nicole and Alisa read on a fifth-grade level.

Data collected over a period of one academic year consisted of: (a) bi-weekly observations, lasting 50 minutes each, between September and May, (b) teacher and student questionnaires administered in October, and (c) interviews with teachers and students in October, January, and May. Analyses followed the methods recommended by Miles and Huberman (1994) 
and Stake (2006). Each case was first analyzed individually in order to understand the findings and assertions that were specific to each teacher and student. After individual case analyses were completed, I conducted a cross-case analysis in order to consider theoretical explanations that recognized the uniqueness of each case but also helped to explain similarities and differences within and across settings and participants (Noblit \& Hare, 1988). Throughout both levels of analysis, I engaged in an inductive approach (LeCompte, Preissle, \& Tesch, 1993; Wolcott, 2005) where I first identified patterns and phenomena in the data without imposing a theoretical view from the onset of data analysis.

\subsection{Available Reading Identities}

Forty of the 153 observations conducted contained one or more statements where teachers explicitly explained to their classes how they identified someone as a reader. Table 1 shows the characteristics teachers attached to each available reading identity, and Table 2 shows the frequency that teachers described each identity to their students.

"Poor readers" were classified in terms of the practices they did not engage in. When teachers explained to their classes what it meant to be a poor reader, they explained that such students did not participate in class, learn from texts, or have the ability to solve their reading difficulties. For example, in October Mrs. Baker explained to her class that, "Being a poor reader is a shame because it means that you cannot understand most of what you read. You might be able to pick out some simple facts, but poor readers can't do much more than that."

On the other hand, teachers described "good readers" in terms of the practices they actively engaged in. Teachers said that "good readers" understood most of what they read and shared their ideas about texts with the class. However, teachers did not seem to think that reading always came easily to good readers. They explained that one practice that separated "good 
readers" from "poor readers" was that "good readers" were able to recognize and respond to their comprehension problems. Mrs. O'Reilly told her class that "Good readers know when something is confusing, and they take the time to figure it out. They use a strategy to help them or they ask someone for help. They don't just skip over it which is something that poor readers do."

A third identity available to students was that of "becoming a good reader." Students who held this identity embodied the characteristics of "poor readers" but engaged in the practices of "good readers." Teachers explained to their classes that "becoming a good reader" took time and that the only way it would happen would be if students started to try out and engage in the behaviors of "good readers." Mrs. Harding told her students: "If you want to become a good reader then you have to work hard at it... You have to use these strategies we've been talking about and you have to ask for help ... You need to say what you think. These are ways that you show you are trying to become a better reader."

\subsection{How Reading Identities Influenced Teachers' Decisions with Struggling Readers}

Seventy-seven of the observations contained one or more statements where teachers explained to their students how they identified them as readers. Table 3 shows how often each teacher told her students that she identified them as poor readers, good readers, or working towards becoming good readers. Across all three classes, students were more likely to be told that their teacher identified them as "poor readers" rather than good ones. However, teachers also told their students that they wanted them to "become good readers" on a regular basis. In Mrs. O'Reilly's and Mrs. Harding's classrooms, students heard this statement most frequently.

To help students enact the "good reader" identity, teachers attempted to scaffold them into the practices of "good readers" by providing comprehension strategy instruction during an average $30 \%$ of the observations for approximately 27 minutes each time. Teachers modeled 
how to apply strategies and asked students to share their successes and struggles with using strategies as they read. Students read texts, engaged in discussions about texts, and completed assignments that required them to use texts during $83 \%$ of the observations.

The teachers' identification of students as "good readers," "poor readers," or those who were "becoming good readers" had significant consequences for the kinds of instruction and support students received. The teachers explained to their classes an average of once a month that many students needed extra help and they would only work with people who practiced the habits of "good readers" or demonstrated that they wanted to "become good readers" as they defined it. For example, Mrs. Baker told her class: "Remember that I am not going to help you if you don't want it. So if you're not trying to help yourself ... if you aren't trying out these strategies, then I am not going to help you. You have to show me that you are trying - that you want to become a good reader."

\subsection{Struggling Readers' Understandings of Reading Identities}

In interviews and on questionnaires, the participating students identified themselves as "poor readers." Such identification came about because they often had regular comprehension difficulties with the texts they were expected to read in school and learned little from them, had poor grades, and had difficulty participating in class discussions about texts. In considering the reading identities that were available to them, students believed that people could be identified as either "good readers" or "poor readers." Tables 4 and 5 display the reading practices that students associated with each identity. Students never showed any awareness about the "becoming a good reader identity" nor did they ever indicate they might have to transform their practices with texts if they wanted to enact or develop the "good reader" identity. 
As Table 4 shows, like the teachers, the students defined a "poor reader" in terms of the practices he or she did not engage in. However, students believed that "poor readers" did participate in a number of positive practices, such as decoding words. According to Nicole: "I can say the words, and like I think that's something. You have to know how to say the words to read, right? And like sometimes I can learn some things from the book. And I'd like to know more, but I do know something."

The students' understandings of the practices associated with "good reader" also varied from their teachers' definitions. Students explained that "good readers" rarely had comprehension problems, learned from text easily, had a high rate of success with texts, asked difficult questions, and could make important contributions to class discussions. As Alisa explained: "The people who can read good - everyone knows who they are. They understand everything and the questions they ask are really hard... And I don't think they ... have to use all these strategies... I think those things are for people like me who don't get it and just need lots of help."

\subsection{Who Do Struggling Readers Want to Be?}

The students explained at each interview that they liked reading and wanted to be seen as "good readers." They said they enjoyed school and wished they could learn more information from texts. All the students agreed that the reading instruction and assignments their teachers provided were useful and could help them obtain their goals.

However, observations paradoxically revealed that the students did not practice "good reader" habits. In interviews, the students explained that while they valued the practices their teachers requested of them, taking on a "good reader" identity would have social consequences for them that were too costly - that is, they believed that engaging in the teacher's "good 
reading" practices would publicly reveal their weaknesses as readers. Therefore, students stated that they preferred to continue engaging in "poor reader" practices, and learn little in school, rather than endure the consequences of obtaining a negative social identity. Sarah explained: 'I'm not going to ask for help because then people would know I didn't understand the book. That is embarrassing. So I guess I don't really learn much. I'm not going to tell the world I'm a bad reader." Thus, maintaining the "poor reader" identity was a resource that students mobilized in an attempt to prevent their peers from creating a negative identity about them.

\section{Positioning Oneself as a Literacy Learner}

In the previous studies, we noticed how teachers position themselves and their students through language use and the undesirable social identities that students can take on as a result of positioning. When individuals tell stories about their literacy learning what they say and how they say it (the text), as well as where and when they say it (the context) interact relationally to enable the person to position him or herself as a certain kind of literacy learner (Wortham, 2001). In the third and final study, we explore how narratives of literacy learning shape who people are as literacy learners and users.

I ([second author]) present a narrative that was taken from a life history of one European American, female pre-service teacher, Rachel Rosenberg. Rachel's life history was generated as part of a larger study of a group of European-American, female pre-service teachers and how they learned literacy across their life spans. In studying participants' life histories, I specifically focused on their "literacy stories" (Second Author, 2008) or stories they conveyed about their literacy learning and practices. In looking closely at these teachers' literacy stories, I noted how teachers used story as a means for conveying their identity as literacy learners. 
Rachel was a student in the elementary education program at Midwestern University (MU). I served as Rachel's literacy methods course instructor during her second semester of the program. To learn about Rachel's life history, I interviewed her two times for approximately two hours each time. The interview focused on eight domains: general demographic information, home life, family activities, childhood activities, school life, work experiences, college, and teaching. I also observed Rachel during the literacy methods course and conducted archival research to learn about the area and time Rachel grew up in.

Data were analyzed using methods of qualitative and narrative analyses. Following initial rounds of coding, I noticed the vast number of stories that participants told about their literacy learning (160 stories were told across 10 participants including Rachel). I focused my attention on these literacy stories following Gee's (1991) methods for narrative analysis. In studying preservice teachers' literacy stories I noticed how they positioned themselves interactionally (Wortham, 2001) in relation to others in order to enact an identity as a literacy learner. Focusing on their interactional positioning has deepened my understandings of the dialogic interplay between one's literate identity and context and how contexts and interactions influence literate identities.

To demonstrate this process, I focus on one story that Rachel narrated about her high school yearbook teacher. Yearbooks are annually published books that contain pictures of the faculty and students, usually grouped together by grade-level, and pictures of events that took place during the year. In American high schools, there is often a teacher who leads a group of students in developing and publishing the yearbook. In looking closely at Rachel's literacy story, I ask: How does Rachel Rosenberg enact a literate identity by positioning herself in relation to her high school yearbook teacher? 


\subsection{Using Narrative to Position Oneself as a Literacy User}

Rachel Rosenberg was born in 1983 in a small Midwestern community located on one of the Great Lakes. She was raised by her mother Susan Rosenberg, a high school English teacher who invested time and resources into supporting Rachel's literacy learning both at home and in school. Rachel told 22 literacy stories which all compared her former teachers' approaches to supporting her literacy learning with those of her mother. Rachel's most complicated story was told about using the computer in high school and the experiences she had with an older male teacher.

When Rachel was in high school, her mother purchased a computer for the family because many of Rachel's teachers requested that homework be completed using a word processing program. Rachel commented that her mother had a very low proficiency when it came to completing tasks on the computer. Therefore, she often asked Rachel to teach her how to use the computer for tasks like grading papers and communicating with others. Rachel believed her mother valued the computer knowledge she gained in school and encouraged her to use the computer to extend her literacy skills. She said, "My mom was like, 'It's good to have a computer at home. You should definitely have access to these things."

Rachel's experiences with her mother stand in stark contrast to the experiences with her high school yearbook teacher, Mr. Jenkins. Part of Rachel's responsibilities for working on the yearbook included formatting and designing pages, writing, copying, and taking photographs. Given her background in using the computer, Rachel believed she should be able to apply her knowledge to performing such tasks. However, Mr. Jenkins disagreed and did not encourage Rachel or her peers to apply their computer literacy skills to the yearbook. Rachel expressed her frustration in his decision: 
We had a really old guy [Mr. Jenkins] who was our yearbook person. And he was like "I've been doing this since 1963, and I know they have those computer programs to do it now but I think they're silly. Which really sucked, because we had to take this computer class, so we all knew desktop publishing. Like, we'd learned it. We were like, "There's such a better way to do this." And he was like, "No! Rubber cement those pages, cut it out, and ...". [Interviewer: So, where did you take the computer class? At school?] Yeah, we had to take a computer class. So all the people who did yearbook were like, "We'll take desktop publishing and try to convince him to move on and do it on the computer. Like we have the programs at school. Why can't we do it?" He's like, "No!" He's like, "I like it better the old-fashioned, cutting-and-pasting-and-rubber-cementing-it-down way."

In positioning herself interactionally to her "old-fashioned" teacher, Rachel points out how a teacher's instructional choices can influence who students can be as literacy learners. Rachel suggests that Mr. Jenkins justified his instructional choices by relying on his years of experience versus his pedagogical knowledge. Rachel also implies that Mr. Jenkins' years of experience are problematic, because they inhibited him from using newer materials for extending his students' literacy skills. Rachel concludes that her teacher should just "move on and do it on the computer." Yet, Mr. Jenkins refuses to change his methods, leaving Rachel to conclude that because he is a veteran teacher who has been teaching since 1963 that he is impervious to change and stuck in his "old-fashioned" ways.

Through Mr. Jenkins, Rachel positions herself as an agent in her literacy learning. Rachel characterizes herself and her classmates as youth who struggle against the "closed fist" of 
authority to try to secure the materials they needed for their literacy learning. Rachel feels violated because Mr. Jenkins ignores "better ways" of teaching his students, ways that honor the literacy practices they bring into his class, because he prefers his outdated methods. Recounting this story, then, enabled Rachel to position Mr. Jenkins as a teacher who violates her expectations of what a "good" literacy teacher does - that is, a "good" literacy teacher draws on students' interests and strengths in order to help students extend their practices in new directions.

In positioning herself in relation to a teacher whose practices she finds to be limiting, as a pre-service teacher Rachel is able to position herself not only as an agent in her literacy learning but also as a novice teacher who is emerging into best practices for teaching literacy. The storytelling context, however, also influences how Rachel chooses to characterize and position herself and others. In Rachel's case, she was taking classes in which a particular understanding on literacy teaching and learning circulated. Literacy was approached as a social and cultural practice that is best acquired when students' backgrounds and literacy practices are recruited into the classroom.

After telling this story, Rachel explained that she wanted to be a teacher in order to challenge her students by giving them authentic experiences for reading and writing. She also hoped to allow her students to gain access to and proficiency with technology. She expressed that she wanted to continue growing and learning as a teacher and that she felt it was imperative for teachers to get to know their students' backgrounds and family lives and the literacy practices that students engage in outside of school. Rachel explained, "Teachers should really get to know their students and their families and what they're good at. It [students' background knowledge] should be part of the curriculum."

\section{Conclusion}


The three studies of literacy teaching and learning in the U.S. presented here show how language influences identity construction daily, yearly, and across individual lives. While teachers and students use language to position themselves and each other, they also use language to promote specific types of engagement with literacy practices and encourage or marginalize involvement with literacy in and outside of school. Collectively, these studies suggest that teachers do not construct identities for themselves and their students haphazardly; it is with intent that identities are created.

In each study, teachers used language to position themselves or their students as particular types of individuals in relation to the literate acts in their classrooms or lives. In Ms. Wagner's class, the use of narrative allowed her to position herself as an authoritative teacher or agent of "humiliation." She purposefully selected her identity as she believed it would allow her, a white teacher, to be successful in working with students of colour (Phillion \& Connelly, 2004). Race became a mediating factor in the social construction of identity, but in ways counter to what scholars describe as an anti-racist identity - one that questions, challenges and disrupts relationships of power and privilege in schooling (Dei, 2001; Wagner, 2005).

Instead, Ms. Wagner used language to position students morally and ethically in ways that aligned with her values, which was empowering for her but marginalized the students. The focal event, the narrative "My worst mistake," moved students into their own interactional positioning of who they were as ethical and moral people in the smoking incidents. It is Ms. Wagner's interpretation of her role as teacher that leads her into the moment-to-moment linguistic choices she makes, which in turn shapes her students' identities.

Teachers also used language to position students as particular types of readers and to suggest what identities students should develop if they want to be successful in school, another 
form of marginalization. In First Author's study, the teachers used language to position students as particular types of readers. Their descriptions of what it meant to be a good, poor, or someone who was becoming a good reader told students what it meant to be literate and influenced students' beliefs about who they were or could become as readers.

Although students and teachers did not always share the same understandings about the available reading identities, the identities held by the teachers were given prominence in the classrooms. Students were expected to ascribe to the dominant models of identity or risk being marginalized. Furthermore, teachers seemed unaware that students believed there was a social risk in trying to become a good reader and that working towards such an identity required first outing oneself as a poor one. While there is no data that shows why teachers were not aware of this belief, one possible explanation is that students were not provided a way to share their understandings of what it meant to be a good or poor reader and what influenced their actions around reading.

Understanding what adolescents think about their school experiences can have positive changes on teachers' instruction. For example, Cook-Sather and Youens (2007) described a program in the U.S. and England that paired pre-service teachers with middle grades students for direct dialogue around positioning, teaching, and learning. Students regularly shared their thoughts with pre-service teachers on such topics as what makes a good teacher and the instructional practices they were expected to participate in. The researchers found that when preservice teachers were able to hear students' voices, they were more likely to critically reflect on how they viewed students and develop a vision for changing their instructional practices. Such practices can help to affirm students' agency by recognizing that adolescents engage in 
purposeful actions and allow them to contribute to positive changes in the classroom (Moore \& Cunningham, 2006).

However, questions might be raised regarding how the language used by the teachers in Author 1's study would be similar or different from middle grades English teachers. Within the U.S., English teachers are often positioned as being more knowledgeable about developing the reading abilities of adolescents than their peers in math, science, and social studies (Marshall, Smith, \& Schaafsma, 1997). Additionally, the demands of the American policy No Child Left Behind (NCLB, 2001) to have all adolescents meeting or exceeding grade level expectations in reading may put additional pressures on English teachers to change or improve how they teach reading (Lewis \& Moorman, 2007). However, English teachers typically focus their instruction on a particular set of texts, often referred to as the canon, and in helping their students engage in literary criticism around those texts and are not necessarily more knowledgeable about literacy instruction than their peers in other disciplines (Burroughs \& Smagorinsky, 2009). While English teachers can create literacy instruction that responds to the social and cognitive needs of adolescents (Sarroub, Pernicke, \& Sweeney, 2007), such instances appear to be rare in the literature.

Author 2's study also shows how language can be used in classrooms in order to enforce a particular literacy practice. Rachel's experiences highlight the tensions that can arise in classrooms as students learn and attempt to incorporate new literacies into their teachers' lives. While students may engage with multiple literacies and feel comfortable shifting in and out of them, teachers may not feel as competent or see the purpose in engaging with literacy in new and different ways (Lankshear \& Knobel, 2000). 
Rachel's experiences also suggest that negative literacy experiences as a student can later influence how pre-service teachers identify themselves as literacy teachers. Rachel's recognition of her high school experience led her to consider how she might create empowering literacy experiences for her own students that would value and incorporate her students' literate backgrounds. She also appeared open to taking a broader view of literacy which is an integral part of helping students become literate individuals in today's society (Smolin \& Lawless, 2003).

Therefore, a critical component of identity development in literacy is helping teachers understand and analyze their views of literacy and how they use language to promote their views in their instruction (Cervetti, Damico, \& Pearson, 2006). Research conducted in the Netherlands (Ponte, Ax, Beijjard, \& Wubbels, 2004) and Australia (Comber \& Kamler, 2004) has shown teachers can become more aware of their language use with students when given regular opportunities to reflect on their teaching with diverse groups of colleagues. These studies demonstrated that as teachers examined how they used language and positioned students, they were able to recognize the ways their instruction was both helpful and limiting. Ultimately they were able to shift out of a deficit view of thinking and understand their students from a perspective that was broader than the skills they could or could not do in school.

The studies presented here suggest that students may be limited to certain choices about their literate identities because of the power of social positioning in language. They can take on the identities presented by their teachers, and receive praise, or opt for ones less valued and risk marginalization. As we have argued, providing students the space to shape their reading identities, and by extension their development as readers, can help them take greater responsibility over their literacy development without feeling as though they have to assimilate into the dominant culture of school (see also Moje \& Lewis, 2007; Nieto, 2002). Helping 
teachers to critique the models that dominate their classroom is necessary in order to help them expand their view of literacy and literacy instruction but also to develop greater understanding about privilege and power in school. 


\section{References}

Agha A. 2007. Language and Social Relations. New York: Cambridge University Press. Applebee, A. N. (1996). Curriculum as conversation. Chicago: University of Chicago Press.

Austin, J. (1956/1975). How to do things with words (2nd edition). Cambridge, MA: Harvard University Press.

Bakhtin, M. M. (1981). The dialogic imagination. (M. Holquist, Ed.; C. Emerson and M. Holquist,Trans.). Austin: University of Texas Press. (Original work published 1935).

Bakhtin, M. M. (1984). Problems of Dostoevsky's poetics. (C. Emerson, Ed. and Trans.).Minneapolis: University of Minnesota Press. (Original work published 1929).

Bakhtin, M. M. (1986). Speech genres and other late essays. (V. W. McGee, Trans.; C. Emerson and M. Holquist, Eds.). Austin: University of Texas Press. (Original work published 1953).

Bartlett, L. (2007). To seem and to feel: Situated identities and literacy practices. Teachers College Record, 109(1), 51-69.

Bartlett, L. (2005). Identity work and cultural artefacts in literacy learning and use: A sociocultural analysis. Language and Education, 19, 1-9.

Bernhard, J.K., Cummins, J., Campoy, F.I., Ada, A.F., Winsler, A., \& Bleiker, C. (2006). Identity texts and literacy development among preschool English language learners: Enhancing learning opportunities for children at risk for learning disabilities. Teachers College Record, 108, 2380-2405.

Burroughs, R. \& Smagorinsky, P. (2009). The secondary English curriculum and adolescent literacy. In L. Christenbury, R. Bomer, \& P. Smagorinsky (Eds.). Handbook of adolescent literacy research (pp. 170-182). Guilford Press, New York. 
Cervetti, G. Damico, J., \& Pearson, P.D. (2006). Multiple literacies, new literacies, and teacher education. Theory into Practice, 45, 378-386.

Comber, B., \& Kamler, B. (2004). Getting out of deficit: Pedagogies of reconnection. Teaching Education, 15(3), 293-310.

Cook-Sather, A. \& Youens, B. (2007). Repositioning students in initial teacher preparation: A comparative descriptive analysis of learning to teach for social justice in the United States and England. Journal of Teacher Education, 58, 62-75.

Corte, J. E. \& Levine, C. G. (2002). Identity formation, agency, and culture. Mahwah, New Jersey: Lawrence Erlbaum.

Davies, B. \& Harré, R. (1999). Positioning and personhood. In R. Harré \& L. van Langenhove (Eds.) Positioning Theory (pp. 32-52). Blackwell Publishers.

Dei, G. J. S. (2001). Rescuing theory: Anti-racism and inclusive education. Race, Gender, \& Class, 8, 139.

Eckert P. 2000. Linguistic Variation as Social Practice: The Linguistic Construction of Identity in Belten High. Malden, MA: Blackwell Publishers

First Author (in press).

First Author (2009).

First Author (2006).

Georgakopoulou, A. (1998). Conversational stories as performances: The case of Greek. Narrative Inquiry, 8(2), 319-350.

Goffman, E. (1959). The Presentation of Self in Everyday Life. New York: Doubleday.

Gumperz J. 1982. Discourse Strategies. Cambridge, MA: Cambridge University Press. Halliday, M. A. K. and Hasan, R. (1976). Cohesion in English. London: Longman. 
Hymes D. 1964. Introduction: Toward ethnographies of communication. Am. Anthropol 66 (6, part 2): 1-34.

Johnston, P.H. (2004). Choice Words: How Our Language Affects Children's Learning. Stenhouse Publishers.

Kramer-Dahl, A. (2000). Collective Literacy Autobiographies: exploring issues of authority, positioning and discourse. Teaching Education, 11, 99-117.

Labov, W. (1972). The transformation of experience in narrative syntax. In Language in the inner city (pp. 354-396). Philadelphia: University of Pennsylvania Press.

Lankshear, C. \& Nobel, M. (2000). Mapping post-modern literacies: A preliminary chart. In M. Yla-Kotola, J. Suoramta, \& M. Kangas (Eds.), The Integrated Media Machine, Vol. 2 (pp. 15-38). Hameenlinna: Edita Publishers.

LeCompte, M. D., Preissle, J., \& Tesch, R. (1993). Ethnography and qualitative design in educational research, second edition. Academic Press.

Lemke, J. (2000). Across the scales of time: Artifacts, activities and meanings in ecosocial systems. Mind, culture, and activity, 7(4), 273-290.

Lewis, C. (2001). Literacy practices as social acts. Mahwah, New Jersey: Lawrence Erlbaum. Lewis, J. \& Moorman, G. (2007). Federal and state literacy mandates for secondary schools: Responding to unintended consequences. In L.S. Rush, A. J. Eakle, and A. Berger (Eds.) Secondary school literacy: What research reveals about classroom practice (pp. 262288). National Council of Teachers of English.

Luke, A. (1995). When basic skills and information processing just aren't enough: Rethinking reading in New Times. Teachers College Record, 97, 95-115. 
Luke, A. (2004). Teaching after the market: From commodity to cosmopolitanism. Teachers College Record, 106, 1422-1443.

McDermott, R., Goldman, S., \& Varebbe, H. (2006). The cultural work of learning disabilities. Educational Researcher, 35, 12-17.

Marshall, J., Smith, J., \& Schaafsma, D. (1997). Teaching as we're taught: The university's role in the education of English teachers. English Education, 29(4).

Mehan H. 1996. The construction of an LD student. In Natural Histories of Discourse, ed. M Silverstein, G Urban, 253-276. Chicago, IL: University of Chicago Press.

Miles, M. \& Huberman, A.M. (1994). Qualitative data analysis. (Second Edition). Sage Publications.

Moje, E.B. \& Lewis, C. (2007). Examining opportunities to learn literacy: The role of critical sociocultural literacy research. In C. Lewis, P. Enciso, \& E.B. Moje (Eds.). Reframing sociocultural research on literacy: Identity, agency, and power (pp. 15-48). Lawrence Erlbaum Associates, Publishers. Mahwah, New Jersey.

Moore, D.W. \& Cunningham, J.W. (2006). Adolescent agency and literacy. In D. E. Alvermann, K.A. Hinchman, D. W. Moore, S. F. Phelps, \& D. R. Waff (Eds.), Reconceptualizing the Literacies in Adolescents' Lives, Second Edition, (pp. 129-146). Lawrence Erlbaum Publishers, Mahwah, New Jersey.

Nieto, S. (2002). Language, Culture, and Teaching: Critical Perspectives for a New Century. Mahwah, NJ: Erlbaum.

Noblit, G. W. \& Hare, R. D. (1988) Meta-ethnography: Synthesizing qualitative studies (Qualitative Research Methods Series, Vol. 11). Newbury Park, CA: Sage Publications. 
Orellana, M. F. (2007). Moving words and worlds: Reflections from “the Middle.” In C. Lewis, P. Enciso, \& E.B. Moje (Eds.). Reframing sociocultural research on literacy: Identity, agency, and power (pp. 123-136). Lawrence Erlbaum Associates, Publishers. Mahwah, New Jersey.

Packer, M.J., \& Goicoechea, J. (2000). Sociocultural and constructivist theories of learning. Ontology, not just epistemology. Educational Psychologist, 35, 227-241.

Phillion, J. \& Connelly, F.M. (2004). Narrative, diversity, and teacher education. Teaching and Teacher Education, 20, 457-471.

Ponte, P., Ax, J., Beijjard, D. \& Wubbels, T. (2004). Teachers' development of professional knowledge through action research and the facilitation of this by teacher educators. Teaching and Teacher Education, 20, 571-588.

Rogers, R. (2002). Between contexts: A critical discourse analysis of family literacy, discursive practices, and literate subjectivities. Reading Research Quarterly, 37, 248-77.

Ruddell, M. \& Shearer, B. A. (2002). Extraordinary, tremendous, exhilarating, magnificent: Middle school at-risk students become avid word learners with the vocabulary selfcollection strategy (VSS). Journal of Adolescent and Adult Literacy, 45, 352-363.

Sarroub, L.K., Pernicke, T., \& Sweeney, T. (2007). "I was bitten by a scorpion": Reading in and out of school in a refugee's life. Journal of Adolescent and Adult Literacy, 50, 668-679.

Scribner, S. (1984). Literacy in three metaphors. American Journal of Education, 93, 6-21.

Searle, J. (1969). Speech acts. New York: Cambridge University Press.

Second Author (2008). 
Skeggs, B. (2008). Making class through fragmenting culture. In A.M.Y. Lin (Ed.) Problematizing Identity: Everyday Struggles in Language, Culture, and Education, (pp. 35-50). Lawrence Erlbaum Associates, Publishers. Mahwah, New Jersey.

Smolin, L.I. \& Lawless, K.A. (2003). Becoming literate in the technological age: New responsibilities and tools for teachers. The Reading Teacher, 56, 570-77.

Stake, R.E. (2005). Multiple case study analysis. New York: The Guilford Press.

Street, B. V. (2005). Recent applications of new literacy studies in educational contexts. Research in the Teaching of English, 39, 417-423.

Third Author, (2008).

Wagner, A. E. (2005). Unsettling the academy: Working through the challenges of anti-racist pedagogy. Race, Ethnicity and Education, 8(3), 261-275.

Wolcott, H. (2005). The art of fieldwork: Second edition. Altamira Press: New York.

Wortham, S. (2001). Narratives in action: A strategy for research and analysis. New York: Teachers College Press.

Wortham, S. (2006). Learning identity: The joint emergence of social identification and academic learning. Cambridge: Cambridge University Press. 